\title{
The Impact of Globalization on the Spiritual Development of Urban Youth in Africa
}

\author{
Nathan H. Chiroma ${ }^{1 *}$, Jane A Chiroma ${ }^{2}$ \\ ${ }^{I}$ PhD, department of Children and Youth Ministry Pan Africa Christian University Nairobi, Kenya. \\ ${ }^{2}$ PhD, Adjunct Lecturer Department of Leadership, Pan Africa Christian University Nairobi, Kenya.
}

*Corresponding Author: Nathan H. Chiroma, PhD, department of Children and Youth Ministry Pan Africa Christian University Nairobi, Kenya.

\begin{abstract}
This article pursues to determine the impact of globalization on the spiritual development of urban youths in Africa, and how that impacts the mission of the church with urban young people. It further seeks to ascertain how youth workers can foster the spiritual development of young people in a globalized urban context. Spiritual development of young people is foundational to the mission of the church, hence a proper understanding of the impact of globalization on the spiritual development of urban young people in Africa will help both the church and youth workers to accomplish their mission of holistic development of young people. The first part of the article provides introductory background, the second part of the article provides contextual definitions, the third section considers Fowler's theory of spiritual development, the fourth section deals with globalization and the spiritual development of urban youths, and the last section provides the implications, recommendations and conclusion to the article.
\end{abstract}

Keywords: globalization, urban youths, spiritual development, Fowler's theory

\section{INTRODUCTION}

Globalization is a multifaceted trend. What make this trend more multifarious are the numerous understanding and the function of the word. Many argue that globalization is primarily an economic process, however, looking at it closely, one would see clearly that it has profound spiritual implications especially on the spiritual development of young people. Matters of spirituality and religion are often addressed in the globalization discussion. Arguably, Spirituality influences the globalization phenomenon and is, in turn, significantly influenced by globalization. The effects of globalization on various aspects of the life of developing nations has always been controversial. In the recent past there has been an emphasis on theimpact of globalization on African culture, identity and moral values. Adler (2016:90) argues that "globalization can be empowering and coercive invasion that will lead to disintegration of identity if not properly understood within a given context". Kelly (2018:16) alludes that globalization has created division among scholars. Some argue that globalization is devastating especially to Africa while other scholars contend that globalization is a welcome development to Africa. Gurdain (2019:4) assert that those who believed in its meaningfulness claim that globalization has added economic prosperity, and has brought accessibility of foreign goods, and created a great market economy to such an extent that Africa stands to gain because of globalization. They further claim that globalization will contribute to Africa society even as changes are viable in every facet of society. However, most of the arguments have no direct bearing on urban young people and even where it does, it is mainly focused on the economic, cultural and political underpinnings. The population of Africa is becoming younger and younger, and many more of these young people are moving into urban areas in search of a better future, and they are confronted with the realities of globalization as a result it impacts the spiritual development of these young people either positively or negatively.

\section{DEFINING CONCEPTS}

In order to set the tone for this article, key concepts that are used will need to be clearly defined, especially as to their use in the article. Defining the key concepts in this article will enable us to have a common understanding of the subject matter discussed in this article. 


\subsection{Globalization}

Nilson (2010:1191) defines globalization as the system by which diverse economies and societies grow to be more closely incorporated. Similarly, the Oxford Dictionary defines globalization as the emergence of an international network, belonging to an economic and social system. Vladislav (2003:14) defines globalization as one of the most popular social studies of today, but is at the same time an empty term. In 2000 the International Monetary Fund (IMF) recognized four basic aspects of globalization: "trade and transactions, capital movements and investment, migration and movement of people and the spreading of knowledge." In the context of this article, globalization is defined as the progression of the range of collective systems and the intensity in the complexity of inter societal associations.

\subsection{Spiritual Development}

Many definitions of spiritual development have been offered across various fields. Hence, spiritual development has different connotations to different people, however simply defined, spiritual development, in essence, is the natural progression of one faith and growth into maturity. It is the process of being transformed daily into the image and the likeness of Jesus Christ. The term spiritual development has a historical association with different Christian traditions. Tang (2014:20) has suggested three goals of spiritual development which he derives after examining the developmental strands of spiritual formation as proposed by Reed (2011:32). The three goals are namely: 1. Believers acquiring a Christ-likeness at the personal level 2. Believers becoming a people of God at the community level 3. Believers establish the Kingdom of God at the missional level. Arguably according to Tang (2011:45) These three goals reposition God's influence from the personal level to the community level and subsequently, to the missional level where God's people will impact the greater environment. Hence, in this article spiritual development is used to mean the daily effort of the young people to be willing and journeying towards not conforming to the pattern of this word but being transformed in the renewal of their minds to be the agents of transformation that will in turn impact the mission of the church, Romans 12:2. We can then can then conclude that Spiritual development is growth toward Christian maturity and growth into the image and the likeness of Jesus Christ, which is evidenced by the fruit of the spirit.

\subsection{Urban Youth}

Urban youth in the context of this article are young people between the age of 18-30 who are urban dwellers. Urban dwellers in these articles refer to youth who are living in cities and not rural areas. This classification is not based on any biases but for the sake of understanding how globalization affects the spiritual development of these young people.

\subsection{Stages of Spiritual Development}

An effective understanding of spiritual development will require an understanding of the stages of spiritual development. Stages of spiritual development enhances the understanding of spiritual development especially within the context of young people. Many scholars (Kholberg 1989, King 2003, Talbot 2015, etc.) have provided several dimensions regarding the stages of spiritual development. However, in this article I have adopted the work of James Fowler who proposed a framework for spiritual development that is in tandem with my theological leaning on the understanding of spiritual development. Fowler (1974:16) structured his spiritual development stages parallel to the aspects of human development. By doing this, Fowler, (1981:23) suggests that spiritual development is the basic of human existence and that it develops in predictable ways, just as cognition or social behavior or motor skills or the ability to feed oneself. Fowler (1974:23-89) proposes seven stages of faith development that are crucial to not only the understanding of spiritual development but to the application of it therefore especially in the context of youth ministry and I will quote him extensively:

Stage 0: Primal or Undifferentiated stage in which Fowler explains that a very little child learns to depend on the kindness of the world based on how that child is handled by their parents.

Stage 1: Intuitive-Projective stage. Here Fowler believes that children are beginning to be able to use signs and their thoughts. However, he added that children in this stage are very self-focused and inclined to take very exact ideas about evil, the devil or other negative aspects of religion. The ability to sort out reality from fantasy is not well developed. 
Stage 2: Mythic-Literal stage, Fowler explains that information at this stage is organized into stories. These stories, along with moral rules, are understood literally and concretely. There is little ability to step back from the story and formulate an overarching meaning. Justice and fairness are seen as reciprocal. A few people remain in this stage throughout their lives.

Stage3: Synthetic-Conventional stage, Fowler argues that people believe without having critically examined their beliefs. Their beliefs are in what they have been taught and in what they see "everyone else" as believing too. There is a strong sense of identity with the group. People in this stage are not very open to questions because questions are frightening at this point of development. People in this stage place a large amount of trust in external authority figures and tend not to recognize that they are within a belief system "box" as their beliefs are internalized but have not been examined.

Stage 4: Individuative-Reflective, this stage according to Fowler is the stage in which a person begins to recognize they are in what he calls a "box" and look outside it. People in this stage ask questions and see the incongruity or problems in their beliefs. He argued that this can be a very laborious stage as old ideas are now tailored and sometimes rejected altogether. Some people give up on faith altogether at this point but faith can be strengthened in this stage as beliefs become explicitly, personally held. There is a strong reliance on the logic, rational mind and the self.

Stage 5: Conjunctive stage according to Fowler is when a person who has gone through the deconstruction of the Individuative-Reflective stage begins to let go of some of the dependence on their own rational mind and recognize that some experiences are not logical or easily understood at all.

Stage 6: Universalizing stage. Fowler contends that very few people reach this stage, which is characterized by seeing all of humanity as one brotherhood and taking profound, self-sacrificing action to care for all humanity because of this view.

In as much as these stages are appreciated by many, there are also several critics of this theory. In the context of understanding the spiritual development of urban young people in the face of globalization, this theory provides a framework for evaluation.

\subsection{Spiritual Development of Young People and the Mission of the Church}

Young people play a vital role in the mission of the church. Hence, seeing young people through a missional lens will assist the church in placing young people within the center of the church's identity and ministry focus. Such a focus then helps the church to own up to the responsibility of caring for young especially in the welfare of their spiritual development. Investing in the spiritual development of young people for the sake of the mission of the church must be at the center of not just youth ministry but also the center of the church. In that way the responsibility will not just be left in the hands of youth workers but to the whole congregation. This vision according to Cartwright (2011:12) allows young people to comprehend their position in the household of God and create spaces for them to use their talents and abilities judiciously towards accomplishing the mission of the church. The spiritual development of young people and the mission of the church cannot be separated because young people are not only a significant part of future congregational life but are also an essential part of present congregational life.

Parker (2010:15) highlights that a comparable parallel of the important role of the spiritual development of young people to the mission of the church is like the family. He argues in a healthy family, all members of the household have a role to play on regular days as well as on special occasions. This is how the church should function when it comes to the spiritual development of young people as well. The interests and activities of young people should not be limited to a special day or time but should be woven throughout the structure of daily mission of the church. Missional churches comprehend this and seek to have young people within the structure of congregational life. Smith (2003:234) adds that in these churches, young people are not just an add on, but at the center of helping in the fulfillment of the mission of the church.

Investing in the spiritual development of young people is also necessary in growing the body of Christ. Hampton (2016:9) asserts that helping young people in their spiritual development and in their growth with their relationship with God prepares them to serve Christ in all they do. As a result, this supports the congregation and catapults the church to thrive and to accomplish its God given mission. When young people are engaged in service, it does not only prepare them to become future leaders, 
but also allow them to contribute to the mission of the church. Samuels (2016:5) articulates that this is seen many times in the Bible, as God often used young people to do great things.

When young people have a deeper encounter with Christ in their spiritual development and draw closer to Him, then they can come to know and love Him more personally and will be involved in the mission of the church willingly. The more they are convinced of the goodness of this, then they want to know and love Him more and the more they want to be part of His mission through the church.

Gicheru (2013:7) warns that a failure to advance the spiritual development of young people in our congregation, the more we stand the risk of restricting their ability to live out their ability to contribute to the overall mission of the church. In most churches in Africa there is a tendency to think and see young people as merely the "future members or leaders" of the church, which denies the present tense understanding of their involvement in the mission of the church.

\subsection{The Impact of Globalisation in the Spiritual Development of Urban Youths}

The central thesis of this article is to look at how globalization has impacted either positively or negatively the spiritual development of urban youth especially as it relates to the mission of the church. According to UNESCO 2014:1) Africa is a continent of young people with 65\% of the population below the age of 35 , and nearly $50 \%$ under the age of 19 who are mostly urban dwellers. This makes young people key players not only in economic development, but also in the strategic accomplishment of the mission of the church. Young people are constantly under the influence of globalization, however, most may not be consciously aware about globalization in their daily lives Schweitzer (2006:35). This section will look at the positive and the negative impact of globalization in the spiritual development of urban youth.

\subsection{The Positive Impact of Globalization on the Spiritual Development of Urban Youths}

Many scholars fear that globalization has tremendously impacted the spiritual development of urban youth in a very negative way. However, it is important to mention that the impact of globalization on the spiritual development of urban young people is not all about gloom and doom, it carries with it some very positive impact.

First, globalization has provided a global forum for sharing best practices on spiritual development among urban youths. Globalization brought the dimension of helping urban youth to see that spiritual development as God expects it, cut across cultures and physical boundaries. Urban youth are able to check with their counterparts in and across borders what it takes to overcome the hindrances to spiritual development and how to be Christians in their own context. Through globalization young people are able to come close to others without losing their identities not distinctiveness.

Additionally, globalization has also helped youth workers and congregations to measure up with other new trends and developments that enhance the spiritual development of urban youth, especially as it relates to the mission of the church. Through globalization, congregations and youth workers are able to find relevant ideas and approaches to the spiritual development of young people.

Second, globalization has provided an ease in communication and technology that is part and parcel of the culture and subculture of urban youth. Wilson (2003:18) argues that young people through technology and information systems are able to connect and interconnect with the global world. Globalization through the impact of communication and technology has provided an interlinking and opening up the world of urban young people. Dirk (2012:7) pointed out that due to technology, and media, young people around the world have a lot in common to share and depend on each other. This has further provided a basis for breaking cultural barriers, urban young people have a common culture to share. Information also moves very fast and urban young people in many parts of the world. This networking opens the world to urban young people and makes it possible to participate in what is happening in the global circles. Hence, spiritual development of urban young people could be done more largely through this networking and opening spiritual development to many urban young people.

Third, globalization has changed the landscape of social life among urban youths, which provides a healthy soil for the spiritual development of urban youths. Social relationships have been transformed through globalization to help urban youths relate to each other without fear or suspicion and help them to cross several barriers that hinders relationships with people from other cultures. Globalization can provide young people with what Appadurai (1993:297) describes as ethnoscape, a 
landscape where young people see each other as an essential future of the world and help them keep each other accountable.

Chikati (2013:4) adds that globalization through technology has increased involvement of young people in many urban churches. Chikati (2013:8) adds that today the youth are participating in what he describes as "techno Culture" which is seen through the use of internet, computers and modern musical instruments. Urban young people are more engrossed and involved in churches where they are appreciated and given a chance to practice their culture. Globalization has also introduced more freedom among urban youth in the sense of church involvement and decision making. Urban youth are willing to effect change in the different cultural and social beliefs which may have hindered their involvement in the church.

Fourth, globalization has impacted the spiritual development of young people through the framework of glocalization. Sharma describes glocalization as the adaptation of global ideas into locally palatable forms. The church is a larger body, even localized it is also part of the global church. Spiritual development of urban youths will benefit from glocalization in easing the tension that may arise from conflicts of culture. Urban young people are from different cultures and contexts and will see spiritual development through those lenses and sometimes it may result in resistance or even rejection.

Fifth, globalization has positively affected the spiritual development of young people through cosmopolitanism. Yoder (2016:8) argues that Globalization brings forth a geographical and thematic expansion of the scope of urban youth that goes beyond the traditional topics of delinquency, studies of generations, and subculture. This provides a wider and deeper opportunity for spiritual development.

\subsection{The Negative Impact of Globalization on the Spiritual Development of Urban Youths}

Despite its numerous positive impacts, globalization carries with it some negative impact as it relates to the spiritual development of urban youth.

First, globalization has impacted the spiritual development of urban youths through materialism. Materialism is the concept of our life that is measured by what we have. Urban youths are exposed to many forms of wealth and riches, and it sometimes becomes a measure of their life and they keep it as first priority at the expense of transformation into being in the image and the likeness of Christ. Many urban young people tend to lose focus and even neglect their Christian heritage in pursuit of greener pastures.

Second, globalization has contributed to the erosion of moral and cultural values. Urban youth tend to embrace fully the negative influences from other parts of the world without critical evaluation or questions. This has affected spiritual development of urban young people to the point that some have deserted their own cultural values and taken up the urban values and life styles hence losing their own identity. The corrosion of moral values which was apparent through the crimes becoming too common and young people becoming individualistic than communal. On the other hand, Wilson (2003:182) remarks that many urban young people have become individualistic in the way they live. Most urban young people do not care about others, they are self-centered, greedy, materialistic and they have no respect for elders and humanity as a whole.

Third, globalization has impacted the family life in urban areas. Family breaking relationships have been affected due to self-centeredness. The basic family structure in African has been challenged due to globalization. Family, which is the bedrock of spiritual development is no longer at the center of congregational life in most of the urban churches. Urban young people are more and more raised by technology and housemaids than their parents. Relationships among family members have become more transactional than relational. The spiritual development of children and young people is no longer taken seriously by many parents because of globalization.

Fourth, globalization has also impacted the urban churches negatively. In churches, there is a lot of change from traditional and cultural worship styles and teachings to foreign styles of doing things. In fact, there is a lack of the African feel in the worship in many African churches. With this diversion, many urban churches in African are using western models of spiritual development of young people and those models are not contextual nor relevant to the needs of young people. Generally, according to Wilson (2003:183), many churches are losing their significance and are becoming spiritually "cold" 
due to secularization. Many of the urban churches in Africa are slowly changing to the patterns of the world through the influence of education, exposure to other values and lifestyles and choices.

Similarly, globalization also had negative impacts on the involvement of the youth in the church. Sharon (2017:7) adds that access to information through social media for example has resulted in borrowing cultures and lifestyles that are foreign to the African continent. This foreign culture has led to individualistic and foreign modes of worship in most of our urban churches to the extent that it has made the youth to ignore the traditional way of worship.

Fifth, globalization has impacted urban youth through relativism. Relativism is the notion that embraces no absolutes. As a result of exposure to many different cultures and lifestyles through globalization, many urban youth are questioning the authority of the bible which is the basis for their spiritual development. Urban youths are now challenging the cardinal doctrines of scripture and are trying to replace them with modern ideologies that are stemming from relativism. Furthermore, urban youth are no longer depending on the church to guide them in matters of truth and doctrine, rather they depend on their globalized counterparts as that is regarded as loyalty.

The impact of globalization on the spiritual development of urban youth in Africa is real, attention needs to be paid to both the positive and the negative impact in order to help young people to develop spiritually and to contribute meaningfully to the mission of the church.

\subsection{Practical Implications for Youth Ministry}

Globalization provides a huge opportunity for the spiritual development of urban youth if taken in the right direction. There are practical implications for both churches and youth workers if we are to tap into the potentialities of globalization as it affects the spiritual development of urban youths. Globalizations provides powerful processes that open for both threats and opportunities. Hence, we must consider the following implications for youth ministry especially as it relates to the spiritual development of urban youth.

Churches should make conscious efforts to understand globalization and how it interacts with the youth, their culture and their needs in order to serve them in their spiritual development. Urban churches should have an open mind to welcome new creative ideas and relevant ways on how to disciple urban young people in the modern time. Youth workers must engage in all the various avenues that globalization has provided in order to foster the spiritual development of urban young people. The church and youth workers should also make intentional efforts to reach out to parents and families in order to help them understand and appreciate globalization and to equip them on how to respond to the challenges that accompany it. Lastly, the reality of globalization is here to stay with us, especially in the urban areas, we must then sensitize young people with the knowledge of both constructive and destructive nature of globalization.

\section{CONCLUSION}

This article has discussed the impact of globalization in the spiritual formation of urban youths in Africa. The article argued that globalization is not only in the area of politics, economy, agriculture etc but it also plays a role in the spiritual development of urban youths. The article further outlined that young people have a vital role in the mission of the church and that globalization has both positive and negative impact in the spiritual formation of urban youths. The article provided some practical implication of the role of the church and youth workers in the spiritual development of urban youth.

\section{BIBLIOGRAPHY}

[1] Adler O., 2016, 'Globalization and human resource management', Research in global strategic management: A Canadian perspective, 1, 90-125.

[2] Appadurai M., 1993, 'Discussion: Fieldwork in the era of globalization', Anthropology and Humanism, 22(1), 297-306.

[3] Cartwright L., 2011, 'A global takeover?', in Mastering the Globalization of Business, 68-83, Palgrave, London.

[4] Chikati, 2013, Youth culture and globalization, University of Illinois Press.

[5] Fowler, J., 1974, 'Toward a developmental perspective on faith', Religious Education, 69(2), 16-35.

[6] Gicheru K., 2013, 'African youth and globalization', Journal of social history, 6-17. 
[7] Gurdain Y., 2019, Youth, globalization, and the church law, Slayton University Press.

[8] Hampton W., 2016, Globalization and Gender, City Pressp Nashville.

[9] International Monetary Fund, 2000, 'Globalization: Threats or Opportunity', 12th April, 2000: IMF Publications.

[10] Kelly J., 2018, Globalization and tradition, University of Chicago Press.

[11] Matthews K. J., 2010, 'Whole-life Transformation', in A. Andrews (Ed.), The Kingdom life: A practical theology of discipleship and spiritual formation', NavPressp Colorado Spring, CO.

[12] Nilson C., 2010, 'The church and globalization', Challenge, 41(2),181-194.

[13] Parker T., 2010, 'Globalization', in Handbook of Political Engagement. Edward Elgar Publishing.

[14] Reed A. H., 2010, Quest for spiritual community: Reclaiming spiritual guidance for contemporary congregations, T\&T Clark Internationalp, New York.

[15] Samuels P., 2016, Globalization: A critical introduction, Macmillan, Palm groove.

[16] Schweitzer B., 2006, Globalization and migration of young people, Sage Publ.

[17] Sharon L., 2017, 'Religion, globalization, and development', Regional studies, 37(6-7), 7-18.

[18] Sheldrake P., 2005, The new Westminster dictionary of Christian spirituality, Westminster John Knox Press, Louisville, KY.

[19] Smith K., 2003, Globalization and human rights, Univ. of California Press.

[20] Tang A., 2014, Till we are fully formed: Christian spiritual formation paradigms in the English-speaking Presbyterian churches in Malaysia, Armour, Singapore.

[21] UNESCO, 2014,Rolling youth, rocking society: Youth take part in the post-modern debate on globalization, United Nations Educational, Scientific and Cultural Organization.

[22] Vladislav K., 2003, 'Arms Industry and the Globalisation Process', Economics of Peace and Security.

[23] Wilson, G., 2003, 'Globalization and the Local Church', in Tim Dearborn, and Scott Paeth, The Local Church in a Global Era: Reflections for a New Century, ed. Max L. Stackhouse, 18-45.

[24] Yoder, M., 2016, Globalization and the Mission of the Church, Bloomsbury Publishing.

Citation: Nathan H. Chiroma, Jane A Chiroma. "The Impact of Globalization on the Spiritual Development of Urban Youth in Africa" International Journal of Humanities Social Sciences and Education (IJHSSE), vol 8, no. 4, 2021, pp. 139-145. doi: https://doi.org/10.20431/2349-0381.0804012.

Copyright: () 2021 Authors. This is an open-access article distributed under the terms of the Creative Commons Attribution License, which permits unrestricted use, distribution, and reproduction in any medium, provided the original author and source are credited. 